\title{
Deeply hidden inside introduced biogenic structures - Pacific oyster reefs reduce detrimental barnacle overgrowth on native blue mussels
}

\author{
Christian Buschbaum ${ }^{\mathrm{a}, *}$, Annika Cornelius ${ }^{\mathrm{a}}$, M. Anouk Goedknegt ${ }^{\mathrm{b}}$ \\ a Alfred Wegener Institute, Helmholtz Centre for Polar and Marine Research, Wadden Sea Station Sylt, Hafenstrasse 43, 25992 List/Sylt, Germany \\ ${ }^{\mathrm{b}}$ NIOZ Royal Netherlands Institute for Sea Research, Department of Coastal Systems, and Utrecht University, P.O. Box 59, 1790 AB Den Burg, Texel, The Netherlands
}

\section{A R T I C L E I N F O}

\section{Article history:}

Received 14 April 2016

Received in revised form 5 September 2016

Accepted 10 September 2016

Available online 12 September 2016

\section{Keywords:}

Barnacles

Mytilus edulis

Crassostrea gigas, non-native species

Facilitation

Epibiosis

\begin{abstract}
A B S T R A C T
In sedimentary coastal ecosystems shells of epibenthic organisms such as blue mussels (Mytilus edulis) provide the only major attachment surface for barnacle epibionts, which may cause detrimental effects on their mussel basibionts by e.g. reducing growth rate. In the European Wadden Sea, beds of native blue mussels have been invaded by Pacific oysters Crassostrea gigas, which transformed these beds into mixed reefs of oysters with mussels. In this study, we determined the spatial distribution of M. edulis and their barnacle epibionts (Semibalanus balanoides) within the reef matrix. Mean mussel density near the bottom was about twice as high compared to the mussel density near the top of an oyster reef, whereas barnacles on mussels showed a reversed pattern. Barnacle dry weight per mussel was on average 14 times higher near the top than at the bottom. This pattern was confirmed by experimentally placing clean M. edulis at the top and on the bottom of oyster reefs at two sites in the Wadden Sea (island of Texel, The Netherlands; island of Sylt, Germany). After an experimental period of five weeks (April and May 2015, the main settlement period of S. balanoides), the number of barnacles per mussel was at both sites significantly higher on mussels near the top compared to near the bottom. We conclude that the oyster reef matrix offers a refuge for M. edulis: inside reefs they are not only better protected against predators but also against detrimental barnacle overgrowth. This study shows that alien species can cause beneficial effects for native organisms and should not be generally considered as a risk for the recipient marine ecosystems.
\end{abstract}

(c) 2016 Elsevier B.V. All rights reserved.

\section{Introduction}

Introduced non-native species can considerably affect native ecosystems and their communities by e.g. altering biodiversity, species interactions, energy flow and evolutionary adaptations (e.g. Vitousek et al., 1997; Grosholz, 2002; Katsanevakis et al., 2014). In the beginning of invasion biology research, direct detrimental impacts of alien organisms on resident species were the most commonly considered consequences of human induced translocation of species across natural barriers (Elton, 1958; Carlton, 1989; Mack et al., 2000; Crooks, 2002). However, influences of non-native species are often more complex and can also include a variety of facilitative effects (Thieltges et al., 2006). It is likely that these are as common as inhibiting effects and therefore, should also be taken appropriately into account when assessing the overall consequences of an alien organism after establishing in a native habitat (Rodriguez, 2006). Especially, non-native habitat-forming species such as epibenthic bivalves and macroalgae can provide additional structures used by native organisms (Crooks, 2002; Gribben et al., 2013). These ecosystem-engineering effects (sensu Jones et al., 1994) are of

\footnotetext{
* Corresponding author.

E-mail address: christian.buschbaum@awi.de (C. Buschbaum).
}

particular importance in coastal ecosystems where epibenthic biotic structures are generally rare such as in the European Wadden Sea (south-eastern North Sea), which is mainly dominated by unconsolidated sediments. For this region, Buschbaum et al. (2006) and Polte and Buschbaum (2008) showed, for instance, that beds of the introduced Japanese seaweed Sargassum muticum (Yendo) Fensholt harbour a much more diverse species assemblage than native macroalgae and provide a suitable habitat for endangered resident fish species. Generally, S. muticum is considered a very aggressive invader and a lot of detrimental impacts on native species are reported from many coastal systems, which could not be confirmed for the Wadden Sea (Staehr et al., 2000; Britton-Simmons, 2004; Harries et al., 2007; Lang and Buschbaum, 2010; Engelen et al., 2015; Davidson et al., 2015).

A further ecologically important, habitat forming, non-native species in the south-eastern North Sea is the Pacific oyster Crassostrea gigas (Thunberg) with its origin at the Japanese coast (Nehring, 2011). It has been introduced for aquaculture purposes in many countries and today, the oyster is almost worldwide distributed including the Wadden Sea (Ruesink et al., 2005; Diederich, 2005, 2006; Cardoso et al., 2007; Padilla, 2010; Troost, 2010; Van der Zee et al., 2012). Here, first free-living Pacific oysters were detected on beds of blue mussels (Mytilus edulis L.) in the 1980s (Reise, 1998; Troost, 2010). Since the late 
1990s, Pacific oysters naturally occur in the entire region outside the aquacultures (Wehrmann et al., 2000; Troost, 2010) and transformed most intertidal mussel beds into mixed aggregations of mussels and oysters (Diederich, 2006; Troost, 2010). This shift was accompanied by an increase in habitat heterogeneity due to newly constructed biogenic reef structures, formed by the large-sized oysters. However, the associated species communities of former pure mussel beds and oyster reefs are largely the same, including a high number of sessile organisms, which live directly attached to the shells of the bivalves (Kochmann et al., 2008; Markert et al., 2009).

One of the most conspicuous epibionts on mussels and oysters are balanids such as the acorn barnacle Semibalanus balanoides (L.). They may completely cover shells of M. edulis and hereby cause a reduction in mussel growth and presumably also other life history traits such as reproduction (Buschbaum and Saier, 2001). Kochmann et al. (2008) and Markert et al. (2009) showed that number and biomass of barnacle epigrowth per area are not very different between mussel beds and oyster reefs. Additionally, Retuschat (2009) found no conspicuous differences in barnacle percent coverage on individual mussel and oyster shells. However, these studies did neither investigate the small-scale distribution of barnacles within oyster reefs, although it has been reported that barnacle cyprid larvae may execute a distinct substrate choice (e.g. Crisp et al., 1985; Le Tourneux and Bourget, 1988; Thompsen et al., 1998; Buschbaum, 2001), nor the spatial occurrence of mussels and oysters within an oyster reef.

The latter was done by Eschweiler and Christensen (2011), who revealed that blue mussels actively migrate from the top to the bottom of an oyster reef in an attempt to escape from crab predation. The resulting mussel distribution is a recurrent pattern (Fig. 1), and we now ask how barnacles respond to this stratification of mussels within oyster reefs. If barnacles follow the same pattern, than the advantage for mussels to keep away from crabs could be foiled. If barnacles show a reversed pattern than the advantage of a predation refuge would be reinforced by diminished overgrowth for the mussels.

To quantify the density of mussels and their barnacle epibionts, we conducted field investigations in different height layers of an oyster reef. We hypothesized that due to the known defence strategy against predation, most M. edulis occur near the bottom where, as a positive side effect, mussels become less overgrown and are, therefore, better protected from detrimental impacts caused by barnacles. This was tested by performing field experiments on barnacle recruitment on mussels at two spatially distinct oyster reefs in the Wadden Sea.

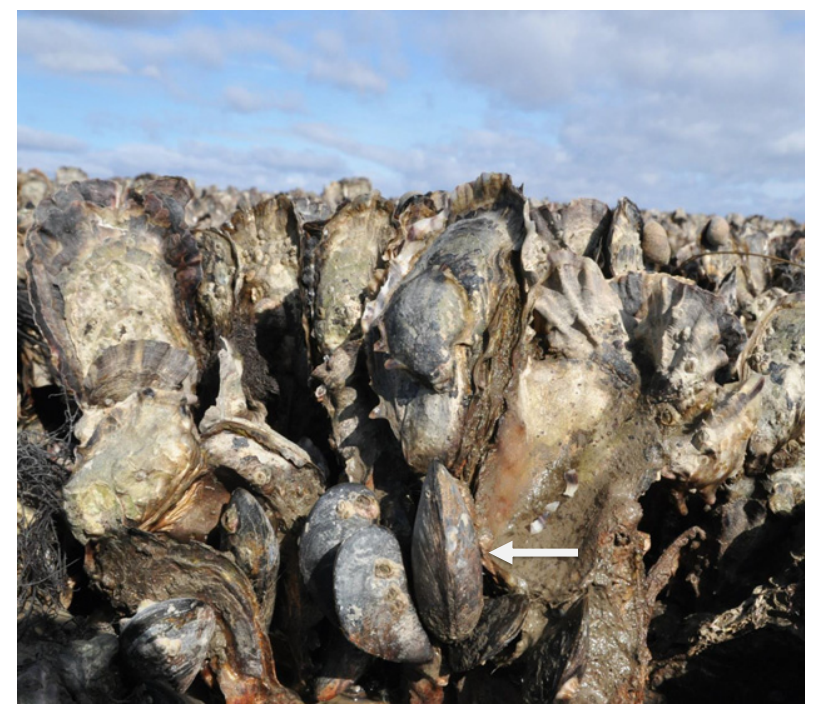

Fig. 1. Mixed reef of introduced Pacific oysters Crassostrea gigas and blue mussels Mytilus edulis (white arrow) in the northern Wadden Sea near the island of Sylt.

\section{Materials and methods}

\subsection{Study area and experimental sites}

Field surveys on mussel abundance and its barnacle epibionts were carried out in a mixed bed of native M. edulis and introduced C. gigas located on tidal flats in the north-east of the island of Sylt in the northern Wadden Sea (Germany, North Sea, $55^{\circ} 02^{\prime} \mathrm{N}, 008^{\circ} 26^{\prime} \mathrm{E}$; Fig. 2). Since the introduction of $\mathrm{C}$. gigas into the area for aquaculture purposes in the mid of the 1980s, all former naturally pure blue mussel beds have been overgrown by Pacific oysters and both mussels and oysters are now occurring in mixed reefs (Nehls and Büttger, 2007; Eschweiler and Christensen, 2011). Tides are semi-diurnal with an average tidal range of about $2 \mathrm{~m}$. Mean water temperature is $15^{\circ} \mathrm{C}$ in summer and $4{ }^{\circ} \mathrm{C}$ in winter and salinity usually remains close to $30 \mathrm{psu}$. For a comprehensive description of the area and its biota see Reise (1985) and Gätje and Reise (1998).

Field experiments on barnacle recruitment on clean M. edulis placed at the top and on the bottom of a Pacific oyster reef were performed at two sites, at the above mentioned area near the island of Sylt and at an oyster reef north-east of the island of Texel in the western Wadden Sea (The Netherlands, $53^{\circ} 09^{\prime} \mathrm{N}, 004^{\circ} 58^{\prime} \mathrm{E}$; Fig. 2). At the latter site, tides have a range of about $1.5 \mathrm{~m}$ and salinity mainly varies from 25 to 31 psu (Van Aken, 2003, 2008a; Cardoso et al., 2007). Average water temperature is $17{ }^{\circ} \mathrm{C}$ in summer and $5{ }^{\circ} \mathrm{C}$ in winter (Van Aken, 2008b).

We chose these two sites and oyster reefs for our field experiments because they represent the end points of a habitat continuum in the Wadden Sea and are, therefore, suitable to test for general and largescale patterns in barnacle recruitment on M. edulis living in Pacific oyster reefs.

\subsection{Position and density of M. edulis inside an oyster reef}

To obtain density distributions of $M$. edulis occurring in different strata of an oyster reef, samples were collected in the uppermost $10 \mathrm{~cm}$ (top layer) and in the layer $10 \mathrm{~cm}$ above the ground (bottom layer) from an oyster reef near the island of Sylt (Fig. 2) by using a stratified random sampling design. The total height of the oyster reef measured from the sediment surface to the uppermost bivalves was about $20 \mathrm{~cm}$. The samples were collected in August 2015 by using a metal frame of $25 \times 25 \mathrm{~cm}\left(625 \mathrm{~cm}^{2}\right)$. A total of six replicate samples per layer were investigated. All mussels with a shell length of $>40 \mathrm{~mm}$, which occurred inside the frame in the respective layer, were counted. Smaller M. edulis were not considered because they are barely overgrown by balanids (Buschbaum and Saier, 2001) presumably to the ability of small-sized mussels to clean their shells with their foot (Theisen, 1972).

\subsection{Barnacle coverage and dry weight on $M$. edulis}

Extent of barnacle overgrowth on M. edulis at the top and bottom of an oyster reef was quantified by analysing barnacle coverage on the mussels, which have been collected by the six replicate samples per layer for the density distribution analysis (see Section 2.2).

Barnacle coverage of each mussel with a shell length of $>40 \mathrm{~mm}$ was estimated to the nearest $25 \%$. Afterwards, barnacles attached to the mussel were scratched off using a knife and then dried at $75{ }^{\circ} \mathrm{C}$ for three days. All investigated mussels of a sample were counted and dry weight of barnacles was determined to the nearest $0.01 \mathrm{~g}$, which allowed calculation of mean barnacle dry weight per mussel for each sample. In total, we examined 145 mussels from the top and $328 \mathrm{M}$. edulis from the bottom layer, respectively. Besides the dominating barnacle $S$. balanoides also the non-native Austrominius modestus occurred in low numbers on the mussels. 


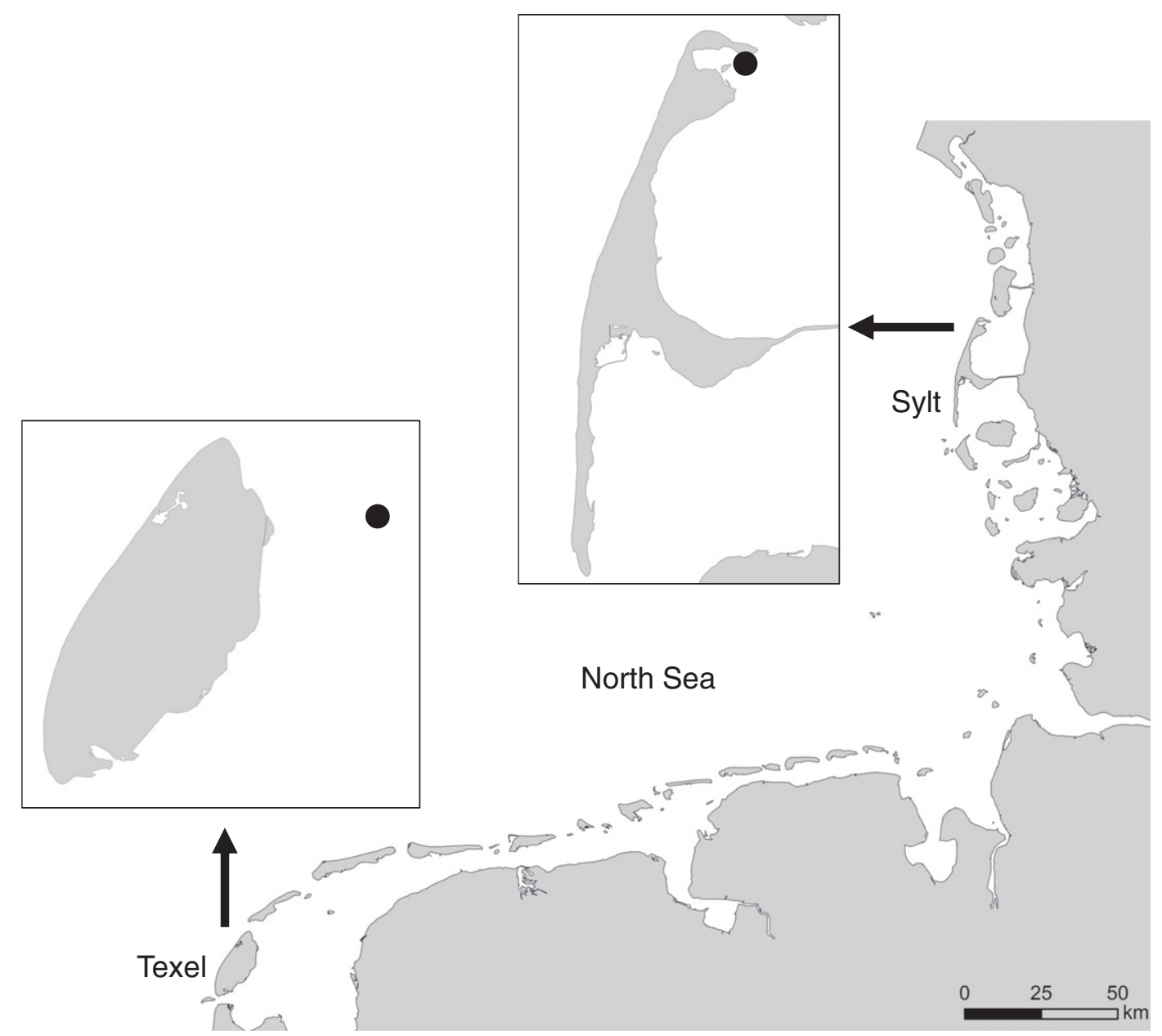

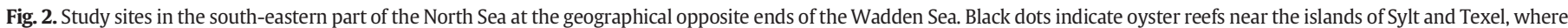
investigations and experiments were carried out.

\subsection{Barnacle recruitment experiments}

Experiments on barnacle recruitment on clean M. edulis placed at the top and on the bottom were conducted on oyster reefs near the islands of Sylt and Texel from mid-April until end of May 2015, which represents the main settlement period of $S$. balanoides in the Wadden Sea (Buschbaum, 2001; Fig. 2). At both sites mussel with a shell length of $40-50 \mathrm{~mm}$ were collected from oyster reefs, cleaned from any overgrowth and individually transferred in pockets made of pvc-netting (pocket size of $10 \times 10 \mathrm{~cm}$, mesh size of $0.5 \mathrm{~cm}$ ). The pockets with mussels were fixed with iron rods in the top and bottom layer of the oyster reefs, respectively. At each site (Sylt and Texel) 40 replicates per treatment (top and bottom) were exposed. The distance between the replicates was at least $50 \mathrm{~cm}$. After an experimental period of 5 weeks (when most barnacles had settled), pockets were resampled and the number of barnacle recruits ( $\leq 3 \mathrm{~mm}$ shell diameter) per mussel was counted.

\subsection{Statistical analysis}

Results are given as arithmetic means and standard deviations (SD). Differences in densities of M. edulis and barnacle dry weight per mussel between the top and the bottom of the oyster reef were analysed using Mann-Whitney $U$ tests.

An analysis of variance (ANOVA) was applied to analyse data of the barnacle recruitment experiments with both experimental sites (Sylt and Texel) and layers in the oyster reef (top and bottom) as fixed factors and numbers of barnacles per mussel as dependent factor. Cochran's test was used to test for homoscedasticity of dependent variances, which revealed heterogeneity despite log-transformation. Because of this violation of assumptions of ANOVA, the data were tested for normality using the Kolmogorov-Smirnoff test, which revealed normal distribution for all data sets. Additionally, it has been shown that ANOVA is quite robust, if the experiment is balanced and the number of replicates per treatment is relatively high, which was the case in our experiment ( $n=40$ per treatment; Underwood, 1997). Therefore, to detect a potential interaction between the fixed factors (site and layer) ANOVA was applied in our field experiment despite heterogeneity of variances. Tukey's Honest-Significant-Difference (HSD) test was used for multiple post-hoc comparisons. Effects were considered to be statistically significant if $p<0.05$.

\section{Results}

\subsection{Mussel density near the top and the bottom of an oyster reef}

The field surveys revealed that density of mussels with a shell size of $>40 \mathrm{~mm}$ differed between the top and bottom layer of an oyster reef in the northern Wadden Sea (Fig. 3). Mean mussel density was $387 \pm$ 60 ind. $\mathrm{m}^{-2}$ at the top and significantly reduced in comparison to the bottom layer with a mean density of $875 \pm 440$ ind. $\mathrm{m}^{-2}$ (Mann-Whitney $U$ test, $p<0.001$ ). 


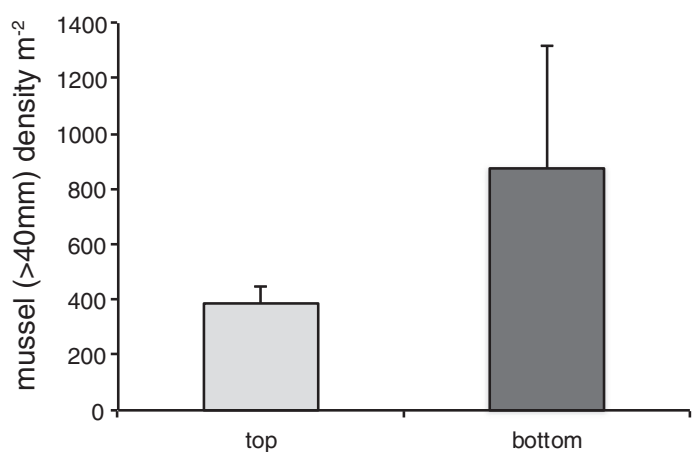

Fig. 3. Mean density $(+S D)$ per square metre of mussels with a shell length $>40 \mathrm{~mm}$ sampled near the top and bottom of an oyster reef.

\subsection{Extent of barnacle overgrowth on M. edulis}

Dry weight of recently recruited S. balanoides was significantly higher on mussels near the top of the oyster reef (1.44 \pm $0.51 \mathrm{~g} \mathrm{mussel}^{-1}$ ) than on M. edulis collected from the bottom layer $\left(0.12 \pm 0.05\right.$ g mussel $^{-1}$, Mann-Whitney U test, $p<0.001$, Fig. 4).

Correspondingly, barnacle percentage cover was largest on mussels from the top layer where only $14 \%$ of the mussels had no or few barnacles, $61 \%$ were up to half covered, $15 \%$ reached up to three-quarters coverage and $10 \%$ of $\mathrm{M}$. edulis were nearly completely overgrown with balanids. Thus, a quarter of all mussels from the top layer were at least half covered with barnacles.

Considering mussels from the bottom layer, 58\% had no or only little barnacle overgrowth and $42 \%$ were up to half covered but no mussels showed a barnacle coverage more than half of the shell surface.

\subsection{Barnacle recruitment experiments}

In our experiments conducted near the islands of Sylt and Texel in spring 2015, barnacle recruitment was significantly higher on mussels placed at the top compared to M. edulis placed on the bottom of the oyster reefs (two-way ANOVA, $\mathrm{F}=99.932$, $\mathrm{df}=1, p<0.0001$; Fig. 5). In addition, experimental site significantly affected $\mathrm{S}$. balanoides recruitment on mussels with higher barnacle recruitment in the northern Wadden Sea (Sylt) compared to the western Wadden Sea (Texel) (two-way ANOVA, $\mathrm{F}=94.422$, df $=1, p<0.0001$ ). In the northern Wadden Sea, mussels from the top layer showed a nearly three-fold and significantly higher barnacle number per mussel $\left(161 \pm 40\right.$ barnacles mussel $\left.^{-1}\right)$ than M. edulis placed at the bottom ( $58 \pm 21$ barnacles mussel $^{-1}$; Tukey's test, $p<0.0001$ ). The same pattern was found in the western Wadden Sea with $60 \pm 47$ barnacles mussel $^{-1}$ for M. edulis placed at the top of the oyster reef, which was significantly higher than the

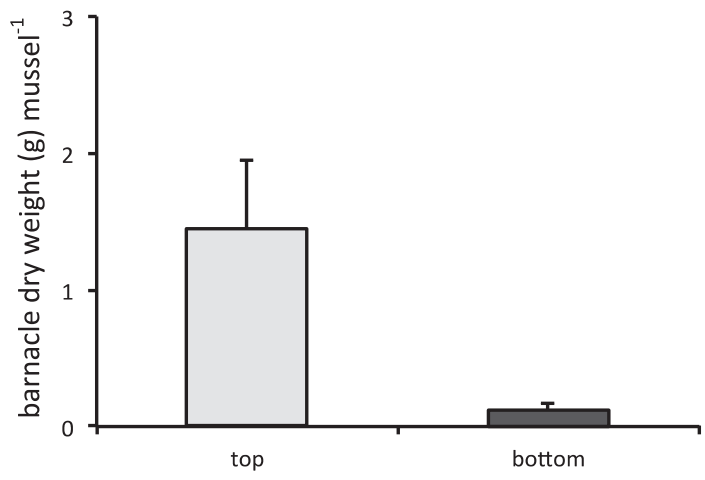

Fig. 4. Mean ( $+\mathrm{SD}$ ) barnacle dry weight $(\mathrm{g})$ of barnacles attached to mussels collected near the top and bottom of an oyster reef.

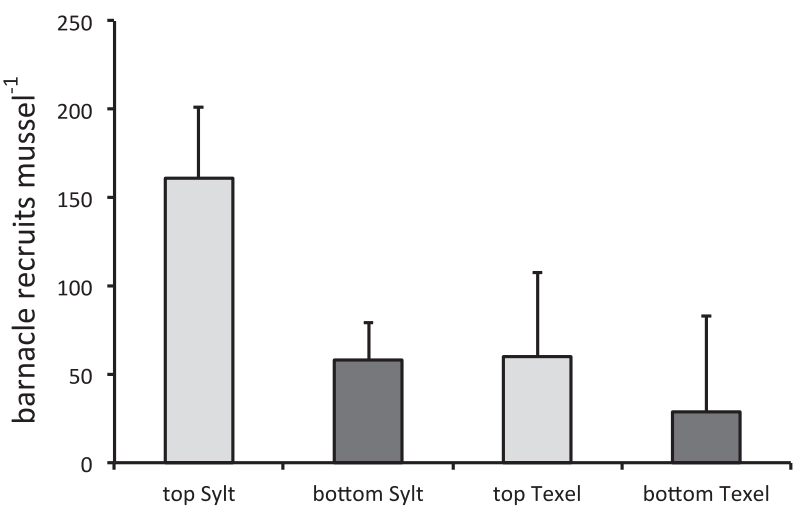

Fig. 5. Mean barnacle number $(+\mathrm{SD})$ on mussels, which were experimentally placed at the top and the bottom of oyster reefs near the islands of Sylt (northern Wadden Sea) and Texel (western Wadden Sea).

number of barnacles recruited on mussels at the bottom (29 \pm 54 barnacles mussel $^{-1}$; Tukey's test, $p<0.01$ ).

We further detected a significant interaction between the two fixed factors, experimental site and layer of the oyster reef (two-way ANOVA, $\mathrm{F}=28.538, \mathrm{df}=1, p<0.0001$ ). This suggests that the difference of barnacle recruitment between mussels placed at the top and the bottom layer depends on overall settlement density in the two areas during the experimental period from April to May 2015.

\section{Discussion}

Our field surveys in the northern Wadden Sea revealed that blue mussels Mytilus edulis and their barnacle epibionts are not equally distributed in mixed aggregations of native mussels and introduced oysters C. gigas. Mussel density was significantly higher near the bottom than near the top of the oyster reef whereas coverage and biomass of barnacle epibionts per mussel was much higher on mussels sampled from the top layer. This barnacle distribution pattern can be caused by an increased recruitment success on mussels occurring at the top of oyster reefs, which was confirmed by the field experiments conducted on tidal flats near the islands of Sylt and Texel.

\subsection{Spatial distribution of M. edulis in Pacific oyster reefs}

Before the introduction of the Pacific oyster C. gigas and their successful establishment in the Wadden Sea, blue mussel beds were the only major epibenthic biogenic structure on the sedimentary tidal flats of the Wadden Sea (Albrecht, 1998; Reise, 1998; Büttger et al., 2008; Kochmann et al., 2008; Markert et al., 2009). Initially, oyster larvae mainly used M. edulis shells as attachment substratum. With increasing oyster densities C. gigas preferred to settle on conspecifics, which progressively transformed mussel beds into oyster reefs. This shift mainly happened in the early 2000s due to a time period of consecutive warm summers and mild winters, which facilitated oyster reproduction and recruitment success (Diederich, 2005; Nehls and Büttger, 2007; Büttger et al., 2008; Schmidt et al., 2008). Since then C. gigas is the main structural component of the mixed reefs of mussels and oysters because of its much larger size, higher biomass, their gregarious behaviour resulting in aggregations of different age classes and the vertical orientation of the Pacific oyster shells (Tamburri et al., 2007; Fig. 1). Consequently, blue mussels had to cope with the situation being pushed in the role of a subtenant in their former self-built habitat. However, this habitat sharing did not result in a suspected reduction of the overall mean density of blue mussels (Büttger et al., 2008; Kochmann et al., 2008; Markert et al., 2009; Troost, 2010), and the oysters were primarily an addition to the existing mussel population. Presumably, the increased structural complexity of the newly established reefs provides 
additional microhabitats for M. edulis within the oyster matrix, which allows co-occurrence of both bivalve species and prevents a reduction in mussel densities (Diederich, 2005).

The high densities of mussels and oysters may lead to a growth reduction in M. edulis. This was shown for mussels occurring at the bottom of an oyster reef, which is a hint for food limitation and, therefore, food competition at deeper layers in an oyster reef (Diederich, 2006; Troost, 2010; Eschweiler and Christensen, 2011). Despite poor food conditions most mussels, however, were predominantly found in this layer and this was not only true for juvenile M. edulis, which are known to settle at deeper layers of mussel beds and oyster reefs (Folmer et al., 2014), but also for large-sized adult M. edulis (this study). Thus, the predominant occurrence of adult M. edulis near the bottom may be caused by an active habitat choice of juveniles at the bottom of an oyster reef but also by a reduction of mussel density at upper layers due to an increased predation pressure by predatory birds and crabs. Additionally, it can also be a consequence of active migration by mussels. Eschweiler and Christensen (2011) conducted field and laboratory experiments, which revealed that adult blue mussels move from the top to the bottom of an oyster matrix when subjected to direct contact with shore crabs Carcinus maenas (L.). It is difficult to assess which process contributes more but both predation at the top and downward migration of adult M. edulis result in the same spatial distribution pattern with most large-sized mussels occurring in deeper layers in the oyster reef where they become less overgrown with barnacles.

\subsection{Barnacle epibionts on M. edulis}

The detected distribution pattern of S. balanoides with most barnacles occurring on mussels at the top of an oyster reef can be a consequence of an active substrate choice by barnacle cypris larvae but can also be caused by post-settlement processes such as higher mortality or increased consumption of barnacles by predators and grazers at the bottom.

Despite the strong limitation of natural hard structures in sedimentary coastal ecosystems such as the Wadden Sea, barnacle larvae may exhibit a pronounced substrate choice. For example, Buschbaum (2001) revealed that the acorn barnacle $\mathrm{S}$. balanoides, which represents the most abundant balanid species in the intertidal zone, was non-randomly distributed within mussel beds and prefers live over dead mussels and shell fragments. Even on the small-scale S. balanoides larvae cypris larvae show a selective settlement with most balanids settling near the siphonal apertures of live M. edulis where food conditions are more favourable resulting in higher barnacle growth rate and reproductive output (Laihonen and Furman, 1986). Our experiments on barnacle recruitment on mussels also indicate an active larval habitat selection because most $\mathrm{S}$. balanoides settled on $\mathrm{M}$. edulis located at the top of an oyster reef at both study sites. The development of oyster reefs in the Wadden Sea strongly increased the availability of hard substrates for sessile organisms. Therefore, with decreasing intraspecific competition between barnacle larvae for suitable attachment surfaces, active substrate choice may be more pronounced than in former pure blue mussel beds. Consequently, predominant barnacle settlement on mussels at the top of an oyster reef is a regular event and can only be concealed in years when larval abundances are exceptional high and also more unfavourable sites are used for settlement. That barnacle recruitment can show strong spatial variations was apparent from our field experiment with fewer barnacles found on mussels in the western Wadden Sea.

Like blue mussels, barnacles are also suspension feeders, which depend on food supply from the water column. Food availability may be higher at the top because an increased amount of water passes the balanids in comparison to deeper layers of an oyster reef where flow velocities are reduced by the complex reef structures. It was already shown by Crisp (1955) that barnacle settlement is encouraged by higher flow velocities and it is very likely that this also occurs in oyster reefs with most barnacle larvae settling on top of an oyster reef to get better food conditions after metamorphosis.

The reduced water movement in deeper layers of oyster reefs also causes an increased sedimentation and the accumulation of biodeposits produced by the mussels and oysters (Albrecht, 1998). This may also contribute to the observed barnacle distribution because these fine particles hamper barnacle feeding activity and cause mortality (Bertness, 1984).

Interestingly, between the mussels and oysters at the bottom of the oyster reefs we detected high numbers of juvenile starfish Asterias rubens L. and of the introduced Pacific shore crabs Hemigrapsus sanguineus (De Haan) and Hemigrapsus takanoi Asakura and Watanabe. These species may prey on juvenile barnacles (Buschbaum, 2002) and in contrast to the native shore crab C. maenas, which leaves the intertidal area during winter, Pacific shore crabs stay in the oyster beds all year round. Therefore, the Pacific crabs can affect the occurrence of S. balanoides already in the barnacle settlement period normally starting in April and predation by crabs and starfish may be a further factor causing low barnacle occurrence in deeper layers of an oyster reef.

Furthermore, Buschbaum (2000) showed that grazing activity by periwinkles Littorina littorea (L.) strongly influences the recruitment success of S. balanoides attached to M. edulis. However, we have not found higher snail densities at the bottom of an oyster reef compared to the top (own unpublished obs.). Therefore, L. littorea could not have contributed to the observed differences in barnacle numbers between the top and bottom.

\subsection{Synthesis}

The spatial distribution of both blue mussels and barnacles results from active habitat choice, predation pressure and abiotic factors such as water flow and related processes (Fig. 6). Also indirect biotic effects can play a role. Enderlein et al. (2003), for example, showed that mussels with barnacle epibionts are more subjected to $C$. maenas predation than unfouled mussels, presumably due to easier handling. This can additionally reduce $M$. edulis abundances at the top of an oyster reef, where mussels are more overgrown with balanids. Thus, the underlying factors can be complex but altogether result in the observed distribution pattern of mussels and barnacles in an oyster reef.

Food is less abundant at the bottom of the oyster matrix, which results in reduced mussel growth rates (Eschweiler and Christensen, 2011). Therefore, the predominant occurrence of mussels in lower layers is a trade-off between less barnacle epibionts and reduced predation by crabs and birds on the one hand but decreased growth in comparison to $M$. edulis positioned at the top (Eschweiler and Christensen, 2011). In terms of barnacle overgrowth, however, oyster reefs provide a refuge for M. edulis. This refuge was not available before the successful establishment of $C$. gigas in the Wadden Sea. In some years during this time, mussel beds were completely covered with detrimental barnacle overgrowth, which may have led to highly variable growth patterns, reproduction successes and resulting mussel population dynamics (Buschbaum and Saier, 2001). We suggest that nowadays oyster reefs may attenuate these strong interannual dynamics in mussel densities by a reduction in predation pressure and extent of barnacle overgrowth in M. edulis (this study) as well as by providing suitable structures for blue mussel settlement.

At many coasts, alien species are about to take over but the oftenenvisioned disaster for native biodiversity has not taken place. It is time to realize that introduced alien species becoming feral have diverse implications for the recipient ecosystems. Particularly, when new biogenic structures arise, a complex interplay between aliens and natives may unfold. The twofold benefit for mussels at the bottom of oyster reefs, finding a refuge there from predators as well as mitigation from barnacle overgrowth, exemplifies such unexpected interactions. 


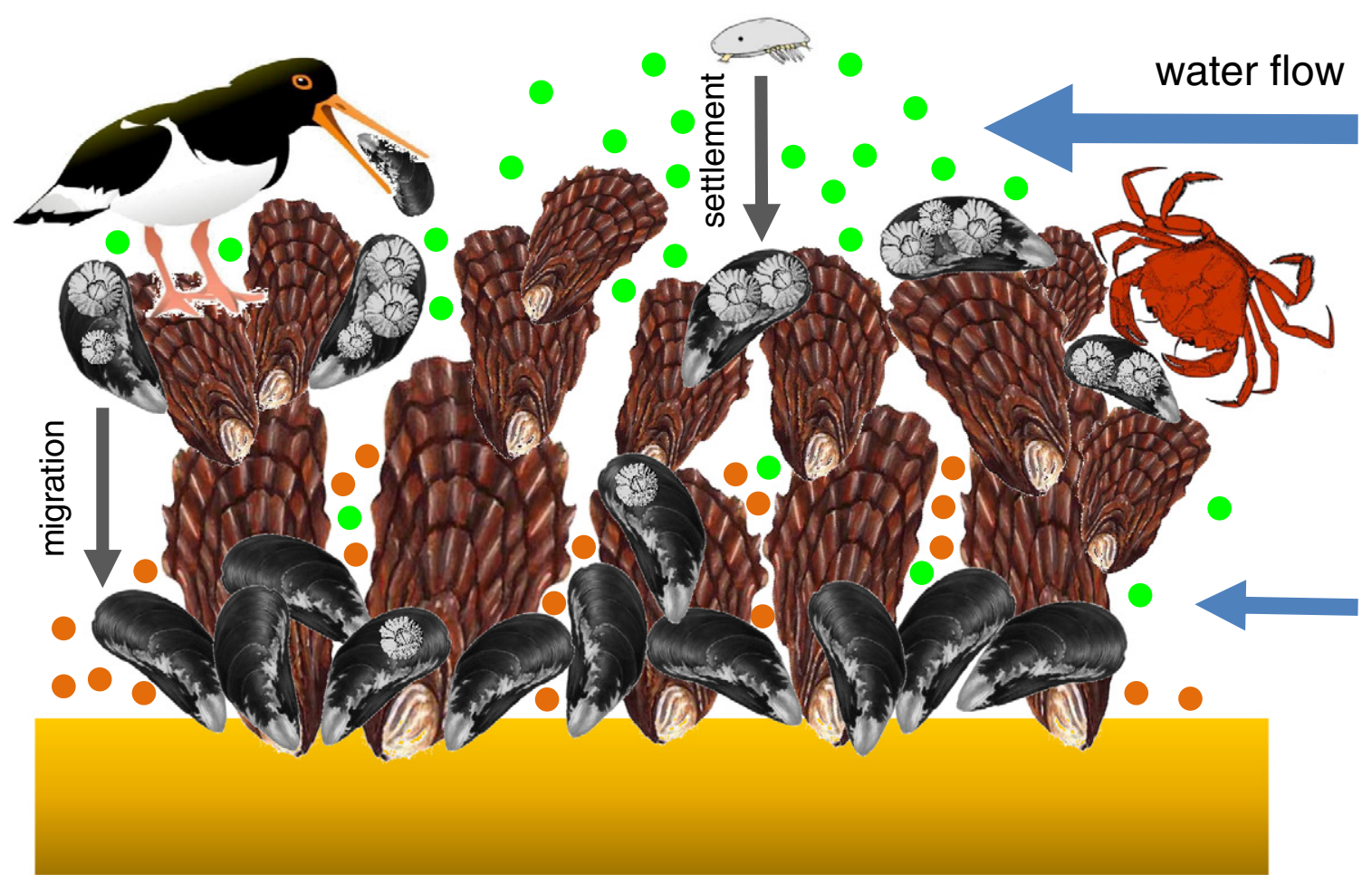

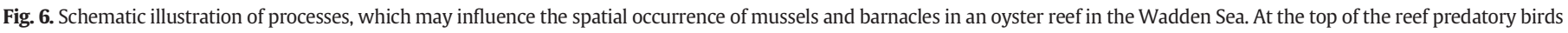

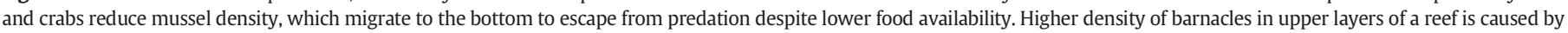
preferential settlement of barnacle cypris larvae on mussels at the top and strong sedimentation near the bottom.

\section{Acknowledgements}

We are grateful to Karsten Reise, Tobias Dolch and two anonymous reviewers for valuable comments on earlier versions of this manuscript. Romy Cartiere and David Thieltges assisted in the field. We also thank the Netherlands Organization for Scientific Research (NWO) and the German Bundesministerium für Bildung und Forschung (BMBF) for funding (NWO-ZKO project 839.11.002).

\section{References}

Albrecht, A.S., 1998. Soft bottom versus hard rock: Community ecology of macroalgae on intertidal mussel beds in the Wadden Sea. J. Exp. Mar. Biol. Ecol. 229, 85-109.

Bertness, M.D., 1984. Habitat and community modification by an introduced herbivorous snail. Ecology 65, 370-381.

Britton-Simmons, K.H., 2004. Direct and indirect effects of the introduced alga Sargassum muticum on benthic, subtidal communities of Washington State, USA. Mar. Ecol. Prog. Ser. $277,61-78$.

Buschbaum, C., 2000. Direct and indirect effects of Littorina littorea (L.) on barnacles growing on mussel beds in the Wadden Sea. Hydrobiologia 440, 119-128.

Buschbaum, C., 2001. Selective settlement of the barnacle Semibalanus balanoides (L.) facilitates its growth and reproduction on mussel beds in the Wadden Sea. Helgol. Mar. Res. 55, 128-134.

Buschbaum, C., 2002. Predation on barnacles of intertidal and subtidal mussel beds in the Wadden Sea. Helgol. Mar. Res. 56, 37-43.

Buschbaum, C., Saier, B., 2001. Growth of the mussel Mytilus edulis L. in the Wadden Sea affected by tidal emergence and barnacle epibionts. J. Sea Res. 45, 27-36.

Buschbaum, C., Saier, B., Chapman, A.S., 2006. How an introduced seaweed can affect epibiota diversity in different coastal systems. Mar. Biol. 148, 743-754.

Büttger, H., Asmus, H., Asmus, R., Buschbaum, C., Dittmann, S., Nehls, G., 2008. Community dynamics of intertidal soft-bottom mussel beds over two decades. Helgol. Mar. Res. $62,23-36$.

Cardoso, J.F.M.F., Langlet, D., Loff, J.F., Martins, A.R., Witte, J.I.J., Santos, P.T., van der Veer, H.W., 2007. Spatial variability in growth and reproduction of the Pacific oyster
Crassostrea gigas (Thunberg, 1793) along the west European coast. J. Sea Res. 57, 303-315.

Carlton, JT., 1989. Man's role in changing the face of the ocean biological invasions and implications for conservation of near-shore environments. Conserv. Biol. 3, 265-273.

Crisp, D.J., 1955. The behaviour of barnacle cyprids in relation to water movement over a surface. J. Exp. Biol. 32, 569-590.

Crisp, D.J., Walker, G., Young, G.A., Yule, A.B., 1985. Adhesion and substrate choice in mussels and barnacles. J. Colloid Interface Sci. 104, 40-50.

Crooks, J.A., 2002. Characterizing ecosystem-level consequences of biological invasions: the role of ecosystem engineers. Oikos 97, 153-166.

Davidson, A.D., Campbell, M.L., Hewitt, C.L., Schaffelke, B., 2015. Assessing the impacts of nonindigenous marine macroalgae: an update of current knowledge. Bot. Mar. 58, 55-79.

Diederich, S., 2005. Differential recruitment of introduced Pacific oysters and native mussels at the North Sea coast: coexistence possible? J. Sea Res. 53, 269-281.

Diederich, S., 2006. High survival and growth rates of introduced Pacific oysters may cause restrictions on habitat use by native mussels in the Wadden Sea. J. Exp. Mar. Biol. Ecol. 328, 211-227.

Elton, C.S., 1958. The Ecology of Invasions by Animals and Plants. John Wiley and Sons. Enderlein, P., Moorthi, S., Röhrscheidt, H., Wahl, M., 2003. Optimal foraging versus shared doom effects: interactive influence of mussel size and epibiosis on predator preference. J. Exp. Mar. Biol. Ecol. 292, 231-242.

Engelen, A.H., Serebryakova, A., Ang, P., Britton-Simmons, K., Mineur, F., Pedersen, M.F., Arenas, F., Fernandez, C., Steen, H., Svenson, R., Pavia, H., Toth, G., Viard, F., Santos, R., 2015. Circumglobal invasion by the brown seaweed Sargassum muticum. Oceanogr. Mar. Biol. Annu. Rev. 53, 81-126.

Eschweiler, N., Christensen, H.T., 2011. Trade-off between increased survival and reduced growth for blue mussels living on Pacific oyster reefs. J. Exp. Mar. Biol. Ecol. 403, 90-95.

Folmer, E.O., Drent, J., Troost, K., Büttger, H., Dankers, N., Jansen, J., van Strahlen, M., Millat, G., Herlyn, M., Philippart, J.M., 2014. Large-scale spatial dynamics of intertidal mussel (Mytilus edulis L.) bed coverage in the German and Dutch Wadden Sea. Ecosystems $17,550-566$

Gätje, C., Reise, K., 1998. Ökosystem Wattenmeer, Austausch-, Transport-, und Stoffumwandlungsprozesse. Springer, Berlin Heidelberg New York.

Gribben, P.E., Byers, J.E., Wright, J.T., Glasby, T.M., 2013. Positive versus negative effects of an invasive ecosystem engineer on different components of a marine ecosystem. Oikos $122,816-824$ 
Grosholz, E., 2002. Ecological and evolutionary consequences of coastal invasions. Trends Ecol. Evol. 17, 22-27.

Harries, D.B., Harrow, S., Wilson, J.R., Mair, J.M., Donnan, D.W., 2007. The establishment of the invasive alga Sargassum muticum on the west coast of Scotland: a preliminary assessment of community effects. J. Mar. Biol. Assoc. U. K. 87, 1057-1067.

Jones, C.G., Lawton, J.H., Shachak, M., 1994. Organisms as ecosystem engineers. Oikos 69, 373-386.

Katsanevakis, S., Wallentinus, I., Zenetos, A., Leppäkoski, E., Cinar, M.E., Oztürk, B. Grabowski, M., Golani, D., Cardoso, C., 2014. Impacts of invasive alien marine species on ecosystem services and biodiversity: a pan-European review. Aquat. Invasions 9, 391-423.

Kochmann, J., Buschbaum, C., Volkenborn, N., Reise, K., 2008. Shift from native mussels to alien oysters: differential effects of ecosystem engineers. J. Exp. Mar. Biol. Ecol. 364, $1-10$.

Laihonen, P., Furman, E.R., 1986. The site of settlement indicates commensalism between blue-mussel and its epibiont. Oecologia 71, 38-40.

Lang, A., Buschbaum, C., 2010. Facilitative effects of introduced Pacific oysters on native macroalgae are limited by a secondary invader, the seaweed Sargassum muticum. J. Sea Res. 63, 119-128.

Le Tourneux, F., Bourget, E., 1988. Importance of physical and biological settlement cues used at different spatial scales by the larvae of Semibalanus balanoides. Mar. Biol. 97, 57-66.

Mack, R.N., Simberloff, D., Lonsdale, W.M., Evans, H., Clout, M., Bazzaz, F.A., 2000. Biotic invasions: causes, epidemiology, global consequences, and control. Ecol. Appl. 10, 689-710.

Markert, A., Wehrmann, A., Kröncke, I., 2009. Recently established Crassostrea-reefs versus native Mytilus-beds: differences in ecosystem engineering affects the macrofaunal communities. Biol. Invasions 12, 15-32.

Nehls, G., Büttger, H., 2007. Spread of the Pacific oyster Crassostrea gigas in the Wadden Sea. Causes and consequences of a successful invasion. BioConsult SH, Husum, on behalf of the Common Wadden Sea Secretariat, Wilhelmshaven, HARBASINS Report, Husum, Germany.

Nehring, S., 2011. NOBANIS - Invasive Alien Species Fact Sheet - Crassostrea gigas. From: Online Database of the European Network on Invasive Alien Species - NOBANIS (www.nobanis.org).

Padilla, D.K., 2010. Context-dependent impacts of a non-native ecosystem engineer, the Pacific oyster Crassostrea gigas. Integr. Comp. Biol. 50, 213-225.

Polte, P., Buschbaum, C., 2008. Native pipefish Entelurus aequoreus are promoted by the introduced seaweed Sargassum muticum in the northern Wadden Sea, North Sea. Aquat. Biol. 3, 11-18.

Reise, K., 1985. Tidal Flat Ecology. Springer, Berlin.

Reise, K., 1998. Pacific oysters invade mussel beds in the European Wadden Sea. Senckenberg. Marit. 28, 167-175.

Retuschat, R., 2009. Mobil oder sessil: Gibt es einen Unterschied im Bewuchs von biogenem Hartsubstrat? Bachelor-Thesis University of Marburg 76 pages
Rodriguez, L.F., 2006. Can invasive species facilitate native species? Evidence of how, when, and why these impacts occur. Biol. Invasions 8, 927-939.

Ruesink, J.L., Lenihan, H.S., Trimble, A.C., Heiman, K.W., Micheli, F., Byers, J.E., Kay, M.C. 2005. Introduction of non-native oysters: ecosystem effects and restoration implications. Annu. Rev. Ecol. Evol. Syst. 36, 643-689.

Schmidt, A., Wehrmann, A., Dittmann, S., 2008. Population dynamics of the invasive Pacific oyster Crassostrea gigas during the early stages of an outbreak in the Wadden Sea (Germany). Helgol. Mar. Res. 62, 367-376.

Staehr, P.A., Pedersen, M.F., Thomsen, M.S., Wernberg, T., Krause-Jensen, D., 2000. Invasion of Sargassum muticum in Limfjorden (Denmark) and its possible impact on the indigenous macoalgal community. Mar. Ecol. Prog. Ser. 207, 79-88.

Tamburri, M.N., Zimmer, R.K., Zimmer, C.A., 2007. Mechanisms reconciling gregarious larval settlement with adult cannibalism. Ecol. Monogr. 77 (2), 255-268.

Theisen, B.F., 1972. Shell cleaning and deposit feeding in Mytilus edulis L. (Bivalvia). Ophelia 10, 49-55.

Thieltges, D.W., Strasser, M., Reise, K., 2006. How bad are invaders in coastal waters? The case of the American slipper limpet Crepidula fornicata in western Europe. Biol. Invasions 8, 1673-1680.

Thompsen, R.C., Norton, T.A., Hawkins, S.J., 1998. The influence of epilithic microbial films on the settlement of Semibalanus balanoides cyprids - a comparison between laboratory and field experiments. Hydrobiologia 375 (376), 1-21.

Troost, K., 2010. Causes and effects of a highly successful marine invasion: Case-study of the introduced Pacific oyster Crassostrea gigas in continental NW European estuaries. J. Sea Res. 64, 145-165.

Underwood, A.J., 1997. Experiments in Ecology: Their Logical Design and Interpretation Using Analysis of Variance. Cambridge University Press, Cambridge.

Van Aken, H.M., 2003. One-hundred-and-forty years of daily observations in a tidal inlet (Marsdiep). ICES Mar. Sci. Symp. 219, 359-361.

Van Aken, H.M., 2008a. Variability of the salinity in the western Wadden Sea on tidal to centennial time scales. J. Sea Res. 59, 121-132.

Van Aken, H.M., 2008b. Variability of the water temperature in the western Wadden Sea on tidal to centennial time scales. J. Sea Res. 60, 227-234.

Van der Zee, E.M., van der Heide, T., Donadi, S., Eklöf, J.S., Klemens Eriksson, B., Olff, H., van der Veer, H.W., Piersma, T., 2012. Spatially extended habitat modification by intertidal reef-building bivalves has implications for consumer-resource interactions. Ecosystems 15, 664-673.

Vitousek, P.M., D'Antonio, C.M., Loope, L.L., Rejmánek, M., Westbrooks, R., 1997. Introduced species: a significant component of human-caused global change. N. Z J. Ecol. 21, 1-16.

Wehrmann, A., Herlyn, M., Bungenstock, F., Hertweck, G., Millat, G., 2000. The distribution gap is closed - fist record of naturally settled Pacific oysters Crassostrea gigas in the East Frisian Wadden Sea, North Sea. Senckenberg. Marit. 30, 153-160. 